\title{
Contamination of Foods by Migration of Some Elements from Plastics Packaging
}

\author{
O. Al-Dayel, O. Al-Horayess, J. Hefni, A. Al-Durahim and T. Alajyan \\ King Abdulaziz City for Science and Technology, Riyadh, \\ Saudi Arabia
}

\section{Introduction}

There are various types of packaging material including paper, board, plastic, metal, glass, wood and other materials. Paper and board packaging accounted for the largest share of global packaging sales in 2003 with $39 \%$ of the total. Plastic packaging accounted for $30 \%$ (rigid and flexible plastics) of the market, with metal packaging accounting for $18 \%$ and glass packaging a further $7 \%$. Other packaging products accounted for the remaining $6 \%$ of the market. Rigid plastics was the fastest growing sector of the market during the period 1999-2003. Around 70\% of overall consumer packaging consumption is used for food and beverage packaging (WPO, 2008). Many different types of plastics are being used as packaging materials. The key components in plastic materials are polymers which are made of units of organic material, and one or more of large molecular weight can be formed as desired. Most polymers are petrochemical compounds with additive materials to give them properties of flexibility, elasticity and resistance to fracture and transparency to light ( OiWah \& Siu-Kay, 2000; Al-Dayel et. al. 2009)

The final plastic material thus is a mix of polymer, additives, manufacturing aids, and side products from the complex polymerization process that were not intentionally added (Bradley \& Coulier 2007).

Low density Polyethylene (LDPE) is used in preparation of most of the hot food packaging. LDPE has high flexibility, and can be affected by organic solvents. It has melting temperature of $110^{\circ} \mathrm{C}$ (wikipedia.org 2012).

High Density Polyethylene (HDPE), has the same uses as those of the low density, but it is much flexible and resistant to organic solvents and to high temperatures. It is used in manufacture of some household appliances, pipes and hoses. It is also used in food packaging which are subject to sterilization temperatures. HDPE is characterized by its ability to isolate the humidity, and its flexibility even at freezing temperature.

Different types of additives, such as antioxidants, stabilizers, lubricants, anti-static and antiblocking agents, have been developed to improve the performance of polymeric packaging materials (Achilias 2007; Susan1992).

The role of food and beverage packaging as a source of contaminants have raised many concerns after the widespread use of such containers; packaging. Any substance (monomers 
and other starting substances, additives, residues) which migrates from the packaging into the food is of concern if it could be harmful to the health (Donatella et. al., 2010; Grob et. al., 2006).

The migration of additives or contaminants from polymeric food packaging to food may be separated into three different, but inter-related, stages: diffusion within the polymer, solvation at the polymer food interface, and dispersion into bulk food (Oi-Wah \& Siu-Kay, 2000). The migration has been showed to increase with fat content and storage temperature (Sanches, et al.,2007).

Antimony does not bioaccumulation, so exposure to naturally occurring antimony through food is very low. Antimony is present in food, including vegetables grown on antimonycontaminated soils, mostly in the low $\mu \mathrm{g} / \mathrm{kg}$ wet weight range or less (WHO, 2003).

Antimony toxicity is dependent on the exposure dose, duration, route (breathing, eating, drinking, or skin contact), other chemical exposures, age, sex, nutritional status, family traits, life style, and state of health (Ross and Adrian, 2009). Chronic exposure to antimony in the air at levels of $9 \mathrm{mg} / \mathrm{m}^{3}$ may exacerbate irritation of the eyes, skin, and lungs (Roper, 1992). Long-term inhalation of antimony can potentiate pneumoconiosis, altered electrocardiograms, stomach pain, diarrhea, vomiting, and stomach ulcers, results which were confirmed in laboratory animals (Roper, 1992). Although there were investigations of the effect of antimony in sudden infant death syndrome, current findings suggest no link. Long-term exposure in experimental animals has shown an increase in the hepatic malfunction and blood changes (ATSDR, 1992). It is not clear yet whether antimony is a human carcinogen. Occupational epidemiology could not confirm evidence of lung carcinogenicity caused by antimony as detected in female rats (Gerhardsson et al. 1982; Jones, 1994; Groth et. al.1986). Furthermore, because the experimental results were not uniform, animal lung carcinogenicity by antimony is still a matter for debate (Jones, 1994; Newton et. Al., 1994; Ross and Adrian, 2009).

This work is an attempt to evaluate the migration of elements from packaging materials into food stuffs. A severe contact condition between food and packaging materials has been created to evaluate the maximum potential migration of elements (Grob et. al.1999).

\section{Experimental}

\subsection{Samples}

Two types of polyethylene samples have been selected from the Saudi market. One is called thermal bag which is commonly used for hot food, and the other one is called food bag which is commonly used for cold and freezing food. Both of these types are made of liner low density polyethylene. The samples elemental concentrations have been obtained using neutron activation analysis (NAA).

\subsection{Neutron Activation Analysis (NAA)}

Samples were irradiated at the McMaster University Reactor in Hamilton, Ontario, Canada. It is a $2 \mathrm{MW}$ open pool research reactor. 
The Gamma ray spectrum acquisition was carried out by the use of a high resolution intrinsic germanium detector.

Two portions of each sample were weighed into a plastic irradiation container. One portion is for short-lived isotope analysis (half life $<24$ hours). This portion is about 4 grams weighed into a $7 \mathrm{ml}$ volume container, and it was irradiated for about 60 seconds using a thermal neutron flux of approximately $6 \times 10^{12} \mathrm{n} / \mathrm{cm}^{2} . \mathrm{s}$. After a short decay period of 6 minutes, the gamma ray spectrum was acquired. The sample was then allowed to decay for further period of 24 hours.

The other portion was for longer lived isotope analysis (half life $>5$ days). Approximately 24 grams of the sample was weighed into a $40 \mathrm{ml}$ container, and was irradiated for 20 minutes using thermal neutron flux of approximately $8 \times 10^{12} \mathrm{n} / \mathrm{cm}^{2} . \mathrm{s}$. After 3 days of decay, the sample was counted for 60 minutes. The sample was again allowed to decay for further period of 18 days and then counted for 2 hours. Results were calculated for each of the four spectra.

\subsection{Quality assurance for NAA analysis}

To assess the analytical process and make a comparative analysis, Standard Reference Material coal sample (SARM-18) from South African Bureau of Standards and a trace element in coal sample from the USA National Institute of Standards and Technology (NIST) (SRM 1632c) were analyzed in the same manner as other samples (Anderson \& Cunningham, 2000; Wang \& Sakanishi, 2004). Table (1) gives the comparison of the certified values and these obtained in this work for each reference materials. The results are generally in a good agreement except for $\mathrm{Sr}, \mathrm{Zr}, \mathrm{Ba}, \mathrm{Sb}, \mathrm{Ba}, \mathrm{Ca}, \mathrm{Eu}, \mathrm{Na}$, and $\mathrm{As}$ in one or other standard reference material samples.

\begin{tabular}{lllllll}
\hline $\begin{array}{l}\text { Element } \\
\mathrm{mg} / \mathrm{kg} \\
(\%)\end{array}$ & in SARM 18 & & & NIST 1632c & \\
$(\mu \mathrm{g} / \mathrm{Kg})$ & This work & RSD & Range $^{\circledR}$ & This work & RSD & Certified Value \\
\hline $\mathrm{Al}(\%)$ & 1.34 & 3 & $2.54-2.61$ & 0.94 & 4 & $0.915 \pm 0.0137$ \\
$\mathrm{Sb}$ & 0.30 & 5 & $0.3^{*}$ & 0.22 & 5 & $0.461 \pm 0.029$ \\
$\mathrm{As}$ & 0.52 & 4 & & 3.5 & 3 & $6.18 \pm 0.27$ \\
$\mathrm{Ba}$ & 91 & 6 & $71-82$ & 70 & 5 & $41.1 \pm 1.6$ \\
$\mathrm{Br}$ & 3.5 & 3 & $3^{*}$ & 20.9 & 3 & $18.7 \pm 0.4$ \\
$\mathrm{Cd}$ & 0.7 & 20 & & $<0.3$ & & $0.072 \pm 0.007$ \\
$\mathrm{Ca}(\%)$ & 0.138 & 4 & $0.17-0.19$ & 0.21 & 4 & $0.145 \pm 0.03$ \\
$\mathrm{Ce}$ & 20.6 & 3 & $21-24$ & 8.2 & 3 & $11.9 \pm 0.2$ \\
$\mathrm{Cs}$ & 1.17 & 4 & $1^{*}$ & 0.473 & 5 & $0.594 \pm 0.010$ \\
$\mathrm{Cl}$ & 54 & 5 & & 1130 & 3 & \\
$\mathrm{Cr}$ & 17.3 & 3 & $14-18$ & 10.4 & 3 & $13.73 \pm 0.20$ \\
$\mathrm{Co}$ & 7.5 & 3 & $5.5-7.2$ & 3.4 & 3 & $3.48 \pm 0.2$ \\
$\mathrm{Cu}$ & 4.9 & 9 & & 6.7 & 6 & $6.01 \pm 0.25$ \\
$\mathrm{Dy}$ & 1.87 & 3 & & 0.57 & 3 & \\
\hline
\end{tabular}




\begin{tabular}{|c|c|c|c|c|c|c|}
\hline $\mathrm{Eu}$ & 0.31 & 3 & $0.3^{*}$ & 0.17 & 3 & $0.124 \pm 0.003$ \\
\hline $\mathrm{Ga}$ & 7.1 & 5 & $8^{*}$ & 2.6 & 6 & $3^{*}$ \\
\hline $\begin{array}{l}\mathrm{Au} \\
(\mu \mathrm{g} / \mathrm{Kg})\end{array}$ & 0.65 & 23 & & $<0.5$ & & \\
\hline Hf & 1.9 & 3 & 1.7-1.9 & 0.44 & 4 & $0.585 \pm 0.010$ \\
\hline In & 0.028 & 12 & & 0.02 & 11 & \\
\hline I & 1.0 & 11 & & 1.5 & 6 & \\
\hline $\operatorname{Ir}(\mu \mathrm{g} / \mathrm{Kg})$ & $<0.7$ & & & $<0.5$ & & \\
\hline Fe $(\%)$ & 0.22 & 3 & $0.28-0.29$ & 0.77 & 3 & $0.735 \pm 0.011$ \\
\hline $\mathrm{La}$ & 10.6 & 3 & $9.0-13$ & 4.7 & 3 & \\
\hline $\mathrm{Lu}$ & 0.207 & 3 & & 0.055 & 4 & \\
\hline $\operatorname{Mg}(\%)$ & 0.056 & 6.5 & $0.1-0.11$ & 0.039 & 8 & $0.0384 \pm 0.0032$ \\
\hline $\mathrm{Mn}$ & 21.5 & 3.2 & $21-23$ & 13.5 & 3 & $13.04 \pm 0.53$ \\
\hline $\mathrm{Hg}$ & $<0.017$ & & $0.04^{*}$ & 0.0802 & 8 & $0.0938 \pm 0.0037$ \\
\hline Mo & 1.13 & 5 & & 0.693 & 9 & $0.8^{*}$ \\
\hline $\mathrm{Nd}$ & 7.5 & 5 & & 3.1 & 5 & \\
\hline $\mathrm{Ni}$ & $<10$ & & & $<6.8$ & & $9.32 \pm 0.51$ \\
\hline $\mathrm{K}(\%)$ & 0.12 & 4 & $0.140-0.150$ & 0.081 & 3 & $0.11 \pm 0.0041$ \\
\hline $\mathrm{Rb}$ & 8.3 & 6 & $6.7-9.5$ & 5.4 & 6 & $7.52 \pm 0.33$ \\
\hline Sm & 1.7 & 5 & $1.9-2.2$ & 0.72 & 5 & $1.078 \pm 0.028$ \\
\hline Sc & 5.1 & 3 & $4.0-4.7$ & 2.0 & 3 & $2.905 \pm 0.036$ \\
\hline Se & 0.2 & 31 & & 1.1 & 5 & $1.326 \pm 0.071$ \\
\hline $\mathrm{Ag}$ & $<0.2$ & & & $<0.1$ & & \\
\hline $\mathrm{Na}(\%)$ & 0.013 & 3 & & 0.052 & 3 & $0.03 \pm 0.005$ \\
\hline Sr & 31 & 15 & $42-45$ & 109 & 4 & $63.8 \pm 1.4$ \\
\hline Та & 0.36 & 3 & $0.3^{*}$ & 0.14 & 3 & \\
\hline Te & $<0.9$ & & & $<0.3$ & & $0.05^{*}$ \\
\hline $\mathrm{Tb}$ & 0.29 & 6 & $0.3^{*}$ & 0.10 & 9 & \\
\hline Th & 3.8 & 3 & $3.0-4.3$ & 1.2 & 3 & \\
\hline Sn & $<11$ & & $1^{*}$ & $<7$ & & $1^{*}$ \\
\hline $\mathrm{Ti}$ & 0.067 & 3 & $0.111-0.116$ & 0.047 & 4 & $0.052 \pm 0.003$ \\
\hline W & 1.5 & 3 & $2^{*}$ & 0.4 & 6 & \\
\hline $\mathrm{U}$ & 1.9 & 3 & $1.5-2.0$ & 0.40 & 4 & $0.513 \pm 0.012$ \\
\hline V & 22 & 3 & $21-25$ & 15 & 4 & $23.72 \pm 0.51$ \\
\hline $\mathrm{Yb}$ & 1.26 & 3 & & 0.34 & 4 & \\
\hline $\mathrm{Zn}$ & 6 & 10 & & 10 & 6 & $12.1 \pm 1.3$ \\
\hline $\mathrm{Zr}$ & 20 & 19 & $62-71$ & $<15$ & & $16^{*}$ \\
\hline
\end{tabular}

@ Range refers to $95 \%$ confidence limits.

* Uncertified value.

RSD: Relative Standard Deviation.

Table 1. Comparison of elemental concentration of the standard reference material (SARM18 and NIST 1632c) in this work and their certified values. 


\subsection{Study of elemental migration}

Four types of food stuffs were examined, water, 30\% ethanol, olive oil and 5\% acetic acid. The aim was to study the immigration of $\mathrm{Al}, \mathrm{Sb}, \mathrm{Cu}, \mathrm{Mg}$, Ti and $\mathrm{Zn}$.

To assess the maximum possible value of elements migration, the samples were prepared under the influence of severe contact conditions between the bag materials and the food stuff. This influence have been created by mixing the bag material, in the form of powder, with the food stuffs and exposing the mixture to high temperature $\left(80-100{ }^{\circ} \mathrm{C}\right)$. Such a contact case cannot be exist in normal human use, but it can show the maximum potential migration.

\subsection{Experimental arrangement and ICP-MS analysis}

Four samples were prepared in four flasks. Each flask contained a mix of $2.5 \mathrm{~g}$ of the sample powder and $25 \mathrm{ml}$ of one of the four food stuffs. The flasks were placed in a shaker at 160 rpm stirring rate at temperature of $100^{\circ} \mathrm{C}\left(80^{\circ} \mathrm{C}\right.$ for ethanol case $)$.

The samples were elementally analyzed using a Perkin-Elmer Sciex Instruments multielement ICP-MS spectrometer, type ELAN6100, equipped with a standard torch, cross flow nebulizer and $\mathrm{Ni}$ sampler and skimmer cones.

\subsection{Quality assurance for ICP-MS analysis}

To assess of the analytical process and make a comparative analysis, Standard Reference Material (SRM), Nist-1640 Natural Water purchased from the National Institute of Standards and Technology (NIST), USA was analyzed in the same manner as all other samples. Table 2 compare the certified values with those obtained in this work. The results are generally in good agreement with the certified values.

\section{Results and discussion}

The elemental concentrations in the samples and the corresponding concentrations migrated to food stuffs are shown in table 3. The results show that the Antimony ( $\mathrm{Sb}$ ) has the highest migrated concentration ratio (37\%), in the acetic acid, followed by Zink (Zn) with $22 \%$, Magnesium with $17 \%$, in ethanol and Titanium (Ti) with $12 \%$, in olive oil. The lowest migration ratio was that of Aluminum (Al) which was only $0.012 \%$, in ethanol. Table 3: Concentration of elements in bags materials and migrated to food stuffs.

\section{Conclusion}

The NAA and the ICP-MS analytical methods used in this work gives good results. These results were confirmed by the analysis of the standard reference materials as shown in tables 1 and 2.

Migration of substances from plastic packaging materials into food stuffs is clearly measured in the conditions which have been created to represent the worst case of contact between packaging material and food stuff. This suggests that a further studies on migration of substances from plastic packaging into food stuffs in the normal conditions should tack place. The results also suggest expected a seriousness harmful effect of using wrong plastic packaging material for heating foods in microwave ovens. 


\begin{tabular}{|c|c|c|c|c|c|}
\hline \multirow[t]{2}{*}{ Elements } & \multicolumn{2}{|l|}{ This Work } & $\rightarrow$ & \multicolumn{2}{|l|}{ Certified values } \\
\hline & $\begin{array}{l}\text { Concentration in } \\
\mathrm{ppb}\end{array}$ & RSD & & $\begin{array}{l}\text { Concentration in } \\
\mathrm{ppb}\end{array}$ & RSD \\
\hline $\mathrm{Li}$ & 49.8 & 1.50 & & 50.7 & 2.76 \\
\hline $\mathrm{Be}$ & 36.4 & 4.95 & & 34.94 & 1.17 \\
\hline B & 264 & 8.60 & & 301.1 & 2.03 \\
\hline $\mathrm{Na}$ & 27800 & 0.34 & & 29530 & 1.05 \\
\hline $\mathrm{Mg}$ & 5800 & 0.50 & & 5819 & 0.96 \\
\hline $\mathrm{Al}$ & 47.4 & 0.32 & $x_{0}$ & 52 & 2.88 \\
\hline $\mathrm{K}$ & 899 & 0.93 & 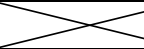 & 994 & 2.72 \\
\hline $\mathrm{Ca}$ & 6990 & 0.97 & 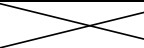 & 7045 & 1.26 \\
\hline $\mathrm{V}$ & 11.9 & 1.16 & - & 12.99 & 2.85 \\
\hline $\mathrm{Cr}$ & 37.1 & 0.45 & 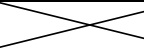 & 38.6 & 4.15 \\
\hline $\mathrm{Mn}$ & 117 & 0.46 & $\gamma$ & 121.5 & 0.91 \\
\hline $\mathrm{Fe}$ & 35.2 & 15.65 & & 34.3 & 4.66 \\
\hline Co & 19 & 0.50 & $\rightarrow$ & 20.28 & 1.53 \\
\hline $\mathrm{Ni}$ & 27 & 1.19 & & 27.4 & 2.92 \\
\hline $\mathrm{Cu}$ & 89.2 & 0.19 & (2) & 85.2 & 1.41 \\
\hline $\mathrm{Zn}$ & 64.7 & 1.36 & $>$ & 53.2 & 2.08 \\
\hline $\mathrm{Ga}$ & 0.198 & 30.20 & $x$ & & \\
\hline As & 27.3 & 1.59 & $>$ & 26.67 & 1.54 \\
\hline Se & 23.7 & 3.95 & $\times$ & 21.96 & 2.32 \\
\hline $\mathrm{Rb}$ & 2.22 & 1.65 & 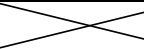 & 2 & 1 \\
\hline $\mathrm{Sr}$ & 108 & 0.40 & $>$ & 124.2 & 0.56 \\
\hline $\mathrm{Mo}$ & 43.5 & 2.04 & 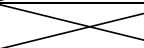 & 46.75 & 0.56 \\
\hline $\mathrm{Ag}$ & 6.48 & 0.39 & 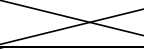 & 7.62 & 3.28 \\
\hline $\mathrm{Cd}$ & 21.9 & 2.14 & $>$ & 22.79 & 4.21 \\
\hline $\mathrm{Sb}$ & 12.6 & 2.85 & - & 13.79 & 1.46 \\
\hline $\mathrm{Te}$ & 0.328 & 26.89 & $>$ & & \\
\hline $\mathrm{Ba}$ & 139 & 0.96 & $>$ & 148 & 1.48 \\
\hline $\mathrm{Tl}$ & 0.146 & 42.60 & $>$ & $<0.1^{*}$ & \\
\hline $\mathrm{Pb}$ & 26.8 & 0.79 & $>$ & 27.89 & 0.50 \\
\hline $\mathrm{Bi}$ & 0.143 & 40.49 & & & \\
\hline $\mathrm{U}$ & 0.834 & 7.41 & 8 & & \\
\hline
\end{tabular}

RSD: Relative Standard Deviation.

Table 2. Comparison of elemental concentration of the reference material (NIST 1640) in this work with the certified values. 


\begin{tabular}{|c|c|c|c|c|c|c|c|c|c|}
\hline \multirow[t]{2}{*}{ Element } & \multirow{2}{*}{$\begin{array}{c}\begin{array}{c}\text { Concentration of } \\
\text { elements in bags } \\
\text { materials }\end{array} \\
\mathrm{ppm} \\
\end{array}$} & \multicolumn{8}{|c|}{ concentation of element migrated to food material and the migration percentage } \\
\hline & & ppm & $\%$ & ppm & $\%$ & Ppm & $\%$ & ppm & $\%$ \\
\hline $\begin{array}{l}\text { Thermal } \\
\text { bag }\end{array}$ & & Water & Migration & Ethanol & Migration & Olive Oil & Migration & Acetic Acid & Migration \\
\hline $\mathrm{Al}$ & 100 & 0.0147 & 0.15 & 0.0127 & 0.13 & 0.073 & 0.7 & 0.181 & 1.8 \\
\hline $\mathrm{Sb}$ & 0.362 & 0.00307 & 8.48 & 0.00372 & 10.28 & 0.000631 & 1.7 & 0.00824 & 22.8 \\
\hline $\mathrm{Cu}$ & 2.7 & 0.00668 & 2.47 & 0.0076 & 2.81 & 0.00224 & 0.8 & Not Detect & \\
\hline $\mathrm{Mg}$ & 246 & 0.0461 & 0.19 & 0.553 & 2.25 & 0.014 & 0.1 & Not Detect & \\
\hline $\mathrm{Ti}$ & 6.6 & 0.0101 & 1.53 & $\begin{array}{l}\text { Below } \\
\text { Detection Limit }\end{array}$ & & 0.00665 & 1.0 & $\begin{array}{l}\text { Below } \\
\text { Detection Limit }\end{array}$ & \\
\hline $\mathrm{Zn}$ & 98 & 0.0175 & 0.18 & 0.0652 & 0.67 & 0.0206 & 0.2 & 0.982 & 10.0 \\
\hline \multicolumn{10}{|l|}{ Food bag } \\
\hline $\mathrm{Al}$ & 768 & 0.0968 & 0.13 & 0.0247 & 0.03 & 0.244 & 0.3 & 0.413 & 0.5 \\
\hline $\mathrm{Sb}$ & 0.283 & 0.00372 & 13.14 & 0.00391 & 13.82 & 0.00066 & 2.3 & 0.0105 & 37.1 \\
\hline $\mathrm{Cu}$ & 4.75 & 0.00638 & 1.34 & 0.0154 & 3.24 & 0.00661 & 1.4 & Not Detect & \\
\hline $\mathrm{Mg}$ & 32 & 0.0274 & 0.86 & 0.555 & 17.34 & 0.0374 & 1.2 & Not Detect & \\
\hline $\mathrm{Ti}$ & 4.4 & 0.0115 & 2.61 & & & 0.055 & 12.5 & 0.000447 & 0.1 \\
\hline $\mathrm{Zn}$ & 52 & 0.026 & 0.50 & 0.124 & 2.38 & 0.163 & 3.1 & 1.15 & 22.1 \\
\hline
\end{tabular}

Table 3. Concentration of elements in bags materials and migrated to food stuffs.

\section{References}

Achilias D. S., Roupakias C., Megalokonomosa P., Lappas A.A., Antonakou E.V. (2007 ) Chemical recycling of plastic wastes made from polyethylene (LDPE and HDPE) and polypropylene (PP) ElsevierB.V. (available online)

Agency for Toxic Substances and Disease Registry (ATSDR), (1992) Toxicological profile for antimony. Atlanta, Georgia, USA: US Department of Health and Human Services, Public Health Service; 1992. p. 160

Al-Dayel O., Al-Horayess O., Hefni J. and Al-Durahim A.,(2009) Trace Elements in Packaging Polymers, Research Journal of Chemistry and Environment, 13, 1, 92

Anderson D and Cunningham W, (2000) Revalidation and Long-Term Standard Reference Materials, J.AOAC.Int.,83, 5, 1121

Bradley, E and Coulier, L, (2007) An investigation into the reaction and breakdown products from starting substances used to produce food contact plastics, Central Science Laboratory, London.

Donatella Restuccia , U. Gianfranco Spizzirri , Ortensia I. Parisi, Giuseppe Cirillo, Manuela Curcio, Francesca Iemma, Francesco Puoci, Giuliana Vinci, Nevio Picci, (2010) New EU regulation aspects and global market of active and intelligent packaging for food industry applications, Food Control 21, 1425

Gerhardsson L, Brune D, Nordberg G.F, Wester P.O, (1982) Antimony in lung, liver and kidney tissue from deceased smelter workers, Scand. J. Work Environ. Health, 8, pp. 201-208

Grob K, Spinner C, Brunner M, Etter R. (1999) The migration from the internal coatings of food cans; summary of the findings and call for more effective regulation of polymers in contact with foods: a review. Food Addit Contam;16. 579

Grob K, Biedermann M, Scherbaum E, Roth M, Rieger K. (2006) Food contamination with organic materials in perspective: packaging materials as the largest and least controlled source? A view focusing on the European situation. Crit Rev Food Sci Nutr;46, 529 
Groth D. H, Stettler L.E , Burg J.R, Busey W.M, Grant G.C, Wong L,(1986) Carcinogenic effects of antimony trioxide and antimony ore concentrate in rats, J. Toxicol. Environ. Health, 18 ), pp. 607-626

Jones R.D , (1994) Survey of antimony workers: mortality 1961-1992, Occup. Environ. Med., 51 , pp. $772-776$

Newton P.E., Bolte H.F., Daly I.W., Pillsbury B.D., Terrill J.B., Drew R.T., Ben Dyke R, Sheldon A.W., Rubin L.F.,(1994) Subchronic and chronic inhalation toxicity of antimony trioxide in the rat, Fundam. Appl. Toxicol., 22, 561-576

Oi-Wah Lau , Siu-Kay Wong (2000) , Contamination in food from packaging material, Journal of Chromatography A, 882, 255

Roper WL, editor. (1992) Toxicological Profile for Antimony and Compounds. Atlanta, Georgia, USA: Agency for Toxic Substances and Disease Registry. Public Health Statement; pp. 1-5

Ross G. Cooper and Adrian P. Harrison, (2009 April) The exposure to and health effects of antimony, Indian J Occup Environ Med. 13(1): 3-10

Sanches Silva, A, et al.,(2007) Kinetic migration studies from packaging films into meat products, Meat Science 77, 238

Susan Brewer M. (1992). , Cooperative Extension Service, University of Illinois at UrbanaChampaign, Circular 1320A.

Wang J, Nakazato T and Sakanishi K, (2004) Microwave digestion with HNO3/H2O2 mixture at high temperatures for determination of trace elements in coal by ICPOES and ICP-MS, J. Analytical Chimica Acta, 514, 115

WHO/SDE/WSH/03.04/74, (2003) Antimony in Drinking-water

WPO (2008) Market Statistics and Future Trends in Global Packaging

WPO - World Packaging Organisation / PIRA International Ltda.

www.wikipedia.org (2012) 


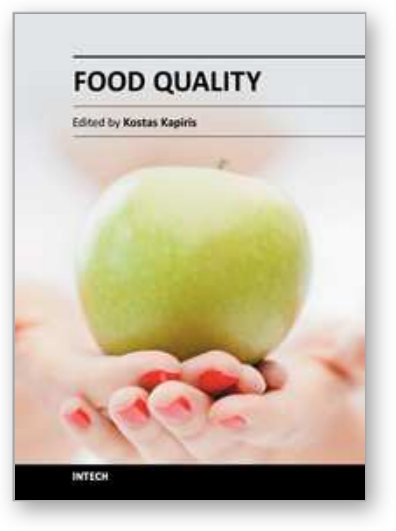

\author{
Food Quality \\ Edited by Dr. Kostas Kapiris
}

ISBN 978-953-51-0560-2

Hard cover, 134 pages

Publisher InTech

Published online 20, April, 2012

Published in print edition April, 2012

The book discusses the novel scientific approaches for the improvement of the food quality and offers food scientists valuable assistance for the future. The detailed methodologies and their practical applications could serve as a fundamental reference work for the industry and a requisite guide for the research worker, food scientist and food analyst. It will serve as a valuable tool for the analysts improving their knowledge with new scientific data for quality evaluation. Two case study chapters provide data on the improvement of food quality in marine and land organisms in the natural environment.

\title{
How to reference
}

In order to correctly reference this scholarly work, feel free to copy and paste the following:

O. Al-Dayel, O. Al-Horayess, J. Hefni, A. Al-Durahim and T. Alajyan (2012). Contamination of Foods by Migration of Some Elements from Plastics Packaging, Food Quality, Dr. Kostas Kapiris (Ed.), ISBN: 978-95351-0560-2, InTech, Available from: http://www.intechopen.com/books/food-quality/contamination-of-foods-bymigration-of-some-elements-from-plastics-packaging

\section{INTECH}

open science | open minds

\section{InTech Europe}

University Campus STeP Ri

Slavka Krautzeka 83/A

51000 Rijeka, Croatia

Phone: +385 (51) 770447

Fax: +385 (51) 686166

www.intechopen.com

\section{InTech China}

Unit 405, Office Block, Hotel Equatorial Shanghai

No.65, Yan An Road (West), Shanghai, 200040, China

中国上海市延安西路65号上海国际贵都大饭店办公楼 405 单元

Phone: +86-21-62489820

Fax: +86-21-62489821 
(C) 2012 The Author(s). Licensee IntechOpen. This is an open access article distributed under the terms of the Creative Commons Attribution 3.0 License, which permits unrestricted use, distribution, and reproduction in any medium, provided the original work is properly cited. 